\title{
СПІЛЬНІ ТА ВІДМІННІ НАПРЯМКИ У ВИВЧЕННІ РЕЛІГІЙНИХ МЕДІЙ У ПРАЦЯХ ЗАКОРДОННИХ ТА УКРАЇНСЬКИХ ДОСЛІДНИКІВ
}

\author{
Наталія Гадьо \\ Львівський національний університет імені Івана Франка, \\ вул. Генерала Чупринки, 49, 79044, Львів, Україна \\ e-mail:natalia_gado@yahoo.com \\ https://orcid.org/0000-0003-0665-573X
}

Схарактеризовано передумови та етапи розвитку досліджень релігійних медій в Iталії, Польщі та Україні. Визначено, що католицька медійна система України свідчить про наближеність до медійних систем Ватикану, Польщі та Італії, особливо спільним контентом і тенденцією до конвергенції медій у значенні зближення і взаємовпливу. Узагальнено закордонний досвід та визначено головні напрямки наукових розвідок італійських і польських науковців та спільне і відмінне в українських дослідженнях релігійної комунікації. Запропоновано періодизацію українських досліджень. Визначено прогалини і можливі напрямки майбутніх досліджень.

Ключові слова: католицька медіасистема в Україні, засоби соціальної комунікації (ЗСК), католицькі медіа, католицьке телебачення, католицьке радіо, католицькі видавництва, друковані видання, дослідження релігійної комунікації.

Українські дослідження католицького медіапростору тяжіють до наукових здобутків Італії та Польщі. Ці географічно найближчі країни з найбільшою кількістю католиків (за різними підрахунками приблизно 95\% і 97\% відповідно) є найбільшими осередками католицьких медій з найбільше розвинутими дослідженнями 3 цієї тематики. Католицькі засоби соціальної комунікації (далі - ЗСК) України дуже тісно пов'язані з медіями цих країн: безпосередньо - як взірцями для наслідування, оперативними джерелами інформації, і опосередковано - через єдину доктрину Католицької Церкви для усіх обрядів, що й дає змогу постійно наповнювати контент українських медій щодо її вчення відповідними перекладами.

Польські та італійські науковці спираються на документи Католицької Церкви щодо ЗСК, які можна вважати важливим складником медіадосліджень, оскільки вони, окрім доктринального, мають науково-прикладне значення для медій та їхніх творців.

Практика вивчення ставлення Католицької Церкви до комунікації сягає початку минулого сторіччя, коли дослідження сучасних медій лише розвивалося. А з працями італійських дослідників А. Стефаніцці та Дж. Фосатті, датованими 1964

(C) Гадьо Н., 2019 
роком, починається етап післясоборових студій над вченням про соціальну комунікацію. Зауважуємо синхронний характер досліджень в Італії та Польщі: і за тематикою, і за результатами.

Специфікою досліджень у цих країнах $є$ те, що медіадослідженнями, як і творенням католицьких медій, займаються священики і миряни. Серед перших - голова Папської Ради соціальної комунікації Архиєпископ К. Челлі та один з її секретарів монсеньйор П. Тайге. Ці та інші єрархи регулярно висловлюються щодо трансформаційних процесів сучасної комунікації і самі активно комунікують через світські та католицькі медіа. Дослідження, які здійснили священики, також займають важливе місце у вивченні католицької комунікації як наукової дисципліни. В Італії одним з них є о.-професор А. Спадаро, редактор видання чину єзуїтів «Civita cattolica» (Католицька цивілізація). Він досліджує вплив інтернету на духовність, називає таке поєднання кібертеологією і вивчає як феномени епохи технології Веб 2.0, зокрема, соціальні мережі та блоги. Поділяючи думку також інших дослідників, о. А. Спадаро твердить, що нові форми комунікації суттєво змінюють сучасну культуру, але не основи віри [1]. Колишній директор Телецентру Ватикану (CTV) о. Даріо Вігано від 1994 р. досліджує здебільшого телебачення, форми маніпулятивної комунікації та координати прихильності Церкви до світу медій [2]. До команди науковців, які досліджують критерії ефективності парафіяльного сайту, належить секретар Папської Ради соціальної комунікації о. Лусіо Руїс [3]. А координатор католицького інтернет-проекту «Роре2Үou» о. Паоло Падріні досліджує корисні можливості інтернету і соціальних мереж для батьків та вчителів [4].

У Польщі засновник Інституту медіаосвіти Варшавського університету ім. кардинала С. Вишинського, о.-професор Антоні Лєвек, автор понад 300 наукових публікацій [5]. Професор Папського католицького університету імені Івана Павла II у Кракові о. А. Зволінський охоплює своїми дослідженнями соціальне вчення Католицької Церкви щодо медій, питання анонімності в цифровому світі, небезпек нерефлекторного перегляду телебачення, впливу інтернету на особу. Його трилогія, присвячена слову, зображенню та звукові, є засадничою літературою для вивчення медіасфери людини у навчальних планах польських факультетів журналістики [6]. Вичерпний каталог польської католицької преси посткомуністичного відродження створив лодзький єп.-доктор А. Лєпа, який також проаналізував вплив медій на особу, дослідив складові медіасфери, образ Католицької Церкви в медіях та спеціальне призначення католицьких медій [7]. Грунтовними доробками для вивчення медіакомункації на сучасному етапі розвитку інтернету є праці: о.-професора М. Дрожджа, який обгрунтовує закономірності явища медіатизації, ускладнення діалогу в медіях та можливі загрози приватності, які несе інтернет [8]; о.-доктора Й. Кльоха, який подає католицьку візію інтернету і досліджує застосування сучасних технологій в церковних інституціях [9]; о.-професора А. Адамського, дослідження якого охоплюють вплив цифрового середовища на зміни в комунікації і особливості діяльності священика, яка в інтернеті стає ще більше схожою до роботи журналіста [10].

Узагальнюючи, можна згрупувати головні напрямки та результати досліджень. Місце Католицької Церкви у світі соціальної комунікації вбачають у творенні її засад, вдосконаленні та актуалізації власне католицьких медій, ширенні ії̈ місії через медіа нових можливостей - Веб 2.0. Науковці з'ясовують ставлення світських ЗСК до релігійного життя та досліджують, який образ Католицької Церкви створюють 
сучасні медіа, і доводять, що політика світського медіа щодо Католицької Церкви визначена зорієнтованістю на сенсацію та позицією власника. Тому часто переростає в боротьбу з Церквою та нерозуміння їі природи і місії. Самі ж вчені місію Католицької Церкви розуміють як євангелізаційну, називаючи її комунікацією віри, а соціальну комунікацію - як наслідування Божої комунікації, яка є поміж Святою Трійцею, виокремлюють як «теологію комунікації». Значна частина наукових праць присвячена історії стосунків Церкви і медій, хронології католицького друку, зберіганню видавничих традицій та навіть розвитку вузькоспеціалізованої церковної літератури.

Сьогодні інтернетизацію комунікації розглядають в контексті вчення Католицької Церкви та окремих Понтифіків, особливостей впливу на релігійне і богопосвячене життя, називаючи діяльність священиків «е-душп@стирством». Технологічні можливості інтернету вважають ще одним способом здійснювати місію Католицької Церкви, які хоч і змінюють конфігурацію комунікації та несуть загрози iii автентичності, але все ж «не змінюють їі сутності». Вчені оглядають католицькі інтернет-сервіси, каталогізують їх, дають поради католикам і священикам, як користуватись ними. Про потребу підготовки релігійних журналістів, виховання відчуття відповідальності та культури найчастіше у своїх дослідженнях згадують самі релігійні журналісти. Підставами медіаосвіти вважають католицькі моральні засади і документи Католицької Церкви.

В Україні понад сімдесят років у науковій сфері домінували атеїстичні підходи щодо оцінки та вивчення релігії і пов'язаних 3 нею питань. Найперше українську релігійну пресу від 1930-х рр. досліджували науковці діаспори та журналісти - А. Животко, I. Кревецький, О. Мох, В. Ігнатієнко. Діаспорні видання - О. Фединський, В. Дорошенко, М. Вайда. Сучасну ж історіографію досліджень релігійної комунікації в Україні 1990-2016 рр. можемо умовно поділити на чотири періоди:

1) 1990-1995 pр. - вивчення преси та видавничої діяльності релігійних організацій за перші роки незалежності України, виявлення значення діаспорних і довоєнних видань;

2) 1996-2000 pр. - переважають дослідження релігійної журналістики як окремої сфери діяльності;

3) 2001-2007 рр. - фіксація активізації ролі інтернету для розвитку релігійної журналістики; кації.

4) 2008-2016 pр. - дослідження окремих елементів релігійної інтернет-комуні-

Сучасні українські дослідження цього сегменту журналістикознавства охоплюють широке коло тем: і довоєнні релігійні видання, і особливості нових релігійних ЗСК. Роль релігійних медій у процесах державотворення одним 3 перших у своїх дослідженнях розкриває I. Крупський. У контексті історії преси до теми релігійної періодики звертаються С. Кость та I. Павлюк. Описи релігійних видань подають В. Габор, І. Михайлин, М. Левчук. Релігійно-церковну періодику першої половини ХХ ст. досліджують О. Канчалаба та Ю. Нестеренко.

Етичні аспекти в сучасній церковній пресі досліджує О. Закревська, дослідниця Ю. Комінко розглядає висвітлення релігійно-церковного життя в Україні на сторінках провідних загальнонаціональних видань України та образ Церкви, який творять 
медіа. На конкретних прикладах доведено, що релігійна тематика мусить бути у сфері зацікавлення сучасних медій і мати фахове відображення.

Потребу «вивчення християнських основ журналістики як фундаментальної бази для формування «журналістської деонтології» виявляє П. Александров. Важливість християнської методології для сучасної журналістики вивчають Х. Давидчак, Й. Лось, які вважають її основоположною для публіцистики. Саме релігійну публіцистику вважає важливим сегментом сучасного комунікативного простору М. Бутиріна (М. Солдатенкова), а Є. Юнусова навіть ставить питання нероздільності релігійного дискурсу від існування європейської культури.

Однак інтегральних досліджень релігійних медій в системі української журналістики не так багато. Подібно до інших дослідників, вважаємо «найбільш раннім досвідом вивчення сучасної церковної періодики» [11, с. 333] працю А. Юраша (1996) [12], в якій автор аналізує конфесійні ЗСК та релігійну тематику в суспільно-політичних медіях, проблеми церкви і релігії в Україні та світі. У дослідника також заходимо типологію друкованих релігійних видань і розрізнення понять «релігійна» та «конфесійна» (або церковна) журналістика, де під першою розуміється напрям журналістської творчості, в межах якої висвітлюється світоглядна позиція та діяльність різних релігійних конфесій, а під другою - висвітлення богословського погляду конкретної конфесії. У подальших дослідженнях вчений послідовно висвітлює використання переваг сучасних аудіовізуальних засобів у релігійній журналістиці та перехід релігійної комунікації у середовище інтернету.

Також типологію релігійної преси запропонував у дисертаційному дослідженні I. Скленар (2008) [13]. Професор А. Бойко структурувала тематику релігійної інформації в медіях, подала тлумачення понять «релігійна інформація», «релігійна комунікація» (2009) [14]. Комунікацію усіх християнських конфесій України аналізує у посібнику «Релігія і Церква в ЗМІ» С. Филипчук.

Виявом глобальних трансформацій християнства доби постмодерну є використання інтернету [15, с. 54], саме тому вивчення релігійної інформації найчастіше стосується присутності в цьому інформаційному середовищі. Перші розвідки Л. Филипович (2001) [16] та А. Юраша (2003) [17], присвячені визначенню рівня зацікавленості інтернетом релігійних громад та їхніх медій, засвідчують, що інтернет вони використовують спочатку для внутрішньоцерковної комунікації - документообігу, а згодом і зовнішньої - євангелізаційної.

Пізніше поява інтернет-ресурсів зумовлює й докладніші дослідження. Загальну характеристику сайтів християнських церков 2008 р. дає О. Тищук, кількість сайтів усіх християнських конфесій в мережі станом на 2011 р. порівнює М. Петрушкевич, а С. Козиряцька досліджує структурно-функціональні та типологічні особливості християнських мережевих видань 2013 р. Проблеми співіснування релігії та віртуальної реальності аналізує О. Бегей, А. Смусь досліджує християнські телепрограми у світському та релігійному мовленні. Зростання ролі медій, перш за все інтернету, в роботі релігійних організацій України, фіксує М. Пальчинська і намагається сформулювати критерії оцінки релігійних медій.

Усі журналістикознавчі праці щодо релігійної комунікації можна ще додатково систематизувати і залежно від типу досліджуваних медій (книга, преса, радіо, телебачення, інтернет), зосереджуючись на дослідженнях щодо релігійних ЗСК та релігійної інформації в суспільно-політичних медіях, і беручи до уваги проблема- 
тику. Однак найдоцільнішим вважаємо розглянути праці щодо релігійних медій за конфесійною ознакою. До того ж, детально проаналізувати стан досліджень українських та закордонних вчених щодо католицьких ЗСК, що найбільше стосується нашого дослідження.

За конфесійною ознакою в Україні домінує православ'я, що складає 51,1\% від загальної кількості релігійних організацій, а серед релігійних періодичних видань найбільша частка (40,3\%) належить православним виданням [18, с. 4-9]. Це кількісно відображено і в наукових дослідженнях, серед яких найбільша частина стосується історії та проблем православних медій.

Релігійну пресу початкового етапу існування і сучасну православну пресу досліджують А. Волобуєва, Л. Дениско, В. Денисюк, І. Жердєва, В. Колодний і Л. Филипович, І. Михайлин, Н. Романенко, М. Рожило (М. Левчук), Л. Сачковська, Ю. Снурнікова та А. Стародуб. Значно менше досліджень стосуються комунікації в інтернеті. Православні мережеві видання як складову конфесійного сегмента в інтернеті розглядає С. Козиряцька. М. Рожило вважає православні інтернет-сайти інноваційними каналами релігійної комунікації. Дослідниця також визначає змістове навантаження морально-етичних категорій у релігійних онлайн-текстах, вивчає комунікативний потенціал проповідей на православних сайтах та розглядає контент окремих православних ресурсів, що загалом створює цілісне бачення православної комунікації в інтернеті.

Друге місце в Україні за кількістю медій, зокрема друкованих видань, займають протестантські деномінації - 130 друкованих періодичних видань, тобто 34,5\% від усіх релігійних видань України $[18$, с. 9]. У середині 90-х років активізувалися дослідження протестантських медій, це і праця А. Ігнатуші, присвячена протестантській періодиці та особливостям інституціональної комунікації, контент-аналіз періодичних протестанських видань О. Спис, дослідження В. Глаголюк, О. Лахно, І. Монолатій, М. Мокієнко. Також науковці подають відомості про довоєнні протестантські медіа, роблять спроби їхньої класифікації та періодизації або ж вивчають їх у межах регіональних досліджень. Найповніше сучасну протестантську комунікацію та їі можливий внесок у розвиток української журналістики проаналізував у докторській дисертації М. Балаклицький. Він зробив детальний історіографічний опис, виокремив організаційні принципи, типологічні особливості та функції протестантських медій. Досліджуючи медіатизацію релігії - повернення релігій у публічну сферу через ЗСК - дослідник зробив висновок, що доступність комунікативних технологій, зокрема тенденція Веб 2.0, збільшують шанси релігійних меншин на конкуренцію в медіасфері [19, с. 65].

Католицьку комунікацію, яка кількісно становить 10,6\% усієї релігійної періодики України (видання УГКЦ - 7,2\%, РКЦ - 3,4\%) [18, с. 9] та займає друге місце за кількістю релігійних організацій $[18$, с. 5] представляють згадані праці А. Юраша та I. Скленара.

Довоєнні та сучасні католицькі періодичні видання аналізують О. Вей, О. Канчалаба, Л. Сніцарчук, А. Путова, роль католицької преси в утвердженні морально-релігійних цінностей досліджує Ю. Щербяк, М. Комариця подає зразки католицької критики на сторінках часописів міжвоєнного двадцятиліття.

Частина дослідників розглядає специфіку окремих католицьких видань або видавничу діяльність монаших згромаджень. М. Лозинський дослідив передвоєн- 
ну видавничу діяльність Василіянського Чину у Галичині та роль часопису «Місіонер», I. Зубрицький та В. Передирій - тип та видавничі засади редакції газети «Нова Зоря», О. Рижко досліджувала матеріали літературно-мистецького спрямування цього ж видання. Концепцію висвітлення національних питань на сторінках часопису «Христос наша сила» подав О. Канчалаба, а про вплив видавничої діяльності Братів Менших Капуцинів та медіа РКЦ на Поділлі згадує С. Іскра. Діяльність чотирьох католицьких видавництв («Свічадо», «Місіонер», «Нова зоря», «Апостол») у своєму науковому блозі розглядає І. Ковальчук, а С. Филипчук згадує про католицькі видавництва у системі християнських видавництв України. Проте загалом сучасне католицьке книговидання досліджене неповно.

Вивчення католицького радіомовлення та телебачення обмежилось працею М. Павлюка про 20-річну діяльність радіо «Воскресіння», а також статтями І. Пуцяти та О. Когутич про морально-етичні засади цього ж каналу. Вчення Католицької Церкви щодо соціальної комунікації у своїх дослідженнях розглядають та наголошують на його унікальності Г. Білак, С. Іскра I., М. Перун, М. Петрушкевич, С. Филипчук. 3'ясовуючи походження та передумови появи поняття «соціальна комунікація», про декрет «Inter Mirifica» згадує В. Різун, справедливо називаючи цей документ Другого Ватиканського Собору тим, де вперше запроваджено цей термін і пояснено вмотивованість його використання. Католицьку систему комунікації, включно з вербальними та невербальними засобами, у своєму дослідженні розглядає М. Петрушкевич. Аналізуючи структуру медіа-освітнього та етнічного просторів Католицької Церкви в Україні, В. Крячко акцентує увагу на потребі досліджень інтернетифікації сучасної релігійної діяльності католиків. Однак дослідження католицьких ЗСК в інтернеті все ще мають фрагментарний характер або ж найчастіше стосуються одного з обрядів Католицької Церкви. Римо-католицькі сайти аналізують О. Керц, А. Бондарєв, а греко-католицькі - Т. Різун і О. Рижко. О. Добродум, характеризуючи феномен віртуалізації в католицизмі, окреслює перспективи оптимізації католицького сегменту інтернету. Порівнює документи про комунікацію різних конфесій та окремо досліджує значення комунікації для Ватикану Г. Білак.

Узагальнюючи цей досвід і заповнюючи виявлену прогалину власним дослідженням українських католицьких засобів комунікації в інтернеті, починаючи від 2013 р. [20] зі залученням теоретичних розробок польських та італійських дослідників у цій галузі у дисертаційній праці «Медіастратегії Католицькї Церкви в Україні», виявляємо чергові напрямки досліджень католицької комунікації. Зокрема цікавим було б, на нашу думку, розглянути сучасні мовні особливості католицьких інтернет-виступів, комунікативні стратегії, на яких вони побудовані, та використання в них візуальних засобів, серед яких майже немає інфографіки - графічного подання інформації. Також майже відсутні, особливо в українських реаліях, практичні порадники для релігійних і католицьких журналістів, прес-секретарів та керівників католицьких медій в інтернеті. I якщо в умовах католицької комунікації в Польщі та Італії ця прогалина заповнена частими конференціями, стажуваннями, майстер-класами та обміном досвідом і зв'язками поміж редакціями католицьких медій на правах співпраці, то сегмент українського католицького інтернету, за невеликими винятками та позитивною динамікою, позбавлений таких можливостей. 


\section{REFERENCES}

1. Spadaro A. Connessioni. Nuove forme della cultura al tempo di Internet. Editore Pardes Edizioni. Bologna, 2006. 178 p.

2. Viganò D. Il brusio del pettegolo - Forme del discredito nella società e nella Chiesa, Bologna: Edizioni Dehoniane Bologna, 2016. P. 80.

3. Arasa D. Cantoni L. Ruis L. ReligiousInternetCommunication. Facts, Expirences Trends in the Catholic Church. Rome: Edusc, 2010. $250 \mathrm{~s}$.

4. Padrini P. (Cura di) Catechesi e comunicazione. Efatta Editrice, 2011. $146 \mathrm{~s}$.

5. Lewek A. Podstawy edukacji medialnej i dziennikarskiej. Wydawnictwo Uniwersytetu Kardynała Stefana Wyszyńskiego, Warszawa, 2003. 473 s.

6. Zwoliński A. Dźwięk w relacjach społecznych. Kraków: Wydawnictwo WAM, 2004. 484 s. / Zwoliński A. Obraz w relacjach społecznych. Kraków: Wydawniztwo WAM, 2004. 482 s. / Zwoliński A. Słowo w relacjach społecznych. Kraków: Wydawnictwo WAM, 2003. $452 \mathrm{~s}$.

7. Lepa A. Katalog prasy katolickiej w Polsce. Stan z dnia 31 stycznia 1994 r. Łódź: Archidiecezjalne Wydawnictwo Łódzkie, 1994, 147 s.

8. Drożdż M. Prywatność w sieci - dobro osobiste czy społeczne. Tarnów: Wydawnictwo Biblos, 2015. $320 \mathrm{~s}$.

9. Kloch J. Kościół w Polsce wobec Web 2.0. Wydawnictwo Jedność, Kielce, 2013. 334 s.

10. Adamski A. Kapłan i dziennikarz. Warszawa, 2008. 319 s.

11. Жердєва I. В. Сучасна православна періодика України: історіографія проблеми. Наукові праці історичного факультету Запорізького національного університету. 2012. Вип. 32. С. 339-341.

12. Юраш А. Українська церква у контексті сучасних політичних конфліктів та комунікативних процесів (історико-політичний аспект): дис. ... канд. політ. наук: 23.00.01. Львів, 1996. 245 с.

13. Скленар I. Сучасна релігійна преса України: типологія, характеристика, домінанти: автореф. дис. ... канд. наук із соц. комунікацій: 27.00.04. Київ, 2008. 18 с.

14. Бойко А. Релігія в мас-медіа України: тексти лекцій. Київ: Київ. нац. ун-т ім. Тараса Шевченка, 2009. 158 с.

15. Свистунов С. Глобальні трансформації християнства доби постмодерну. Християнство доби постмодерну: кол. монографія. Київ: [б.в.], 2005. С. 54-69.

16. Филипович Л. Сучасна релігійна ситуація й український Інтернет. Релігійна свобода: мас-медіа, школа і церква як суспільні фактори утвердження. Київ, 2001. № 5. C. $88-89$.

17. Юраш А. Релігія й електронні медіа: взаємодія, протистояння, ігнорація. Телевізійна й радіожурналістика. Львів, 2003. Вип. 5. С. 22-30.

18. Релігійна мережа в Україні: стан і перспективи. Національна безпека і оборона. 2011. №1-2. 36 c.

19. Балаклицький М. Медіатизація протестантизму в Україні 1991-2010 років: монографія. Харків: Харків. іст.-філол. т-во, 2001. 379 с.

20. Гадьо Н. Передумови та особливості трансформації засобів комунікації Католицької Церкви (на прикладі «Радіо Ватикану»). Вісник Львівського університету. Серія журналістика. 2013. Вип. 38. С. 460-468. 


\title{
COMMON AND DIFFERENT IN THE FOREIGN AND UKRAINIAN RESEARCHES OF RELIGIOUS MEDIA
}

\author{
Nataliya Hado \\ Ivan Franko National University of Lviv, \\ Generala Chuprynky Str., 49, 79044, Lviv, Ukraine \\ e-mail:nataliagado@yahoo.com \\ https://orcid.org/0000-0003-0665-573X
}

The development of religious means of social communication in Ukraine began after the adoption of the Law of Ukraine «On Freedom of Conscience and Religious Organizations» in April 1991 which provided legal authority to religious organizations. Than the modern system of religious media in Ukraine has recreated after the declaration of independence of Ukraine and evolved 1991-2009. But Ukrainian media had grown in the matrix of media systems of Italy, Poland and Vatican's media. It is determined that the Ukrainian Catholic media system shows the proximity to the media systems of the Vatican, Poland and Italy, especially the common content and the tendency for convergence of media in the sense of convergence and mutual influence. However, it is in a state of formation and implementation of the concepts of Internet resources using technologies Web 2.0. Convergent signs and the level of technology use Web 2.0 are emerging as a realization of the strategy for improving media.

New technologies and communication tools are very important for Catholic communication, which allow broad access to the teaching of the Catholic Church. Now this is reflected in the emergence and improvement of Catholic media on the Internet. This is considered a continuation of the media strategies of the Catholic Church.

The author gives her own proposed the periodization of historiography of research on religious communication in Ukraine in 1990-2016. Based on the consistent positive attitude outlook of the Catholic Church towards all means of communication six major strategies for media on the Internet have been identified: active creation of Catholic sites and their improvement in accordance with the requirements of time; communication with secular media; media education on the Internet; pastoral work of Internet resource workers; communication among members of the Catholic Church through the Internet; communication with those who do not belong to the Church.

Key words: the Catholic media system in Ukraine, the means of social communication, Catholic media, Catholic television, Catholic radio, Catholic publishing houses, press, main researches of religious communication of Italy and Poland. 